\title{
Electroconvulsive Therapy During the COVID-19 Pandemic
}

\author{
Mislav Škrobo ${ }^{1}$, Vjekoslav Peitl1,2, Ante Silićc ${ }^{1,2}$, Ana Matošić ${ }^{1,2}$, \\ Branka Vidrih ${ }^{1,2}$, Dalibor Karlović ${ }^{1,2}$ \\ ${ }^{1}$ Department of Psychiatry, University Hospital Centre Sestre milosrdnice, Zagreb, \\ Croatia, ${ }^{2}$ School of Medicine, Catholic University of Croatia, Zagreb, Croatia
}

\begin{abstract}
In March 2020, three months after the first cases surfaced in the Chinese city of Wuhan, WHO declared a global pandemic of the novel coronavirus, which by than had already spread through a great number of countries all over the world. In order to protect the health of healthcare workers and patients, activities and measures of disease prevention have been taken; in such circumstances, psychiatry found itself faced with various challenges, one of them being the preservation of the continuity of electroconvulsive therapy (ECT) in patients with severe or refractory psychiatric disorders. Such patients are a priority and demand immediate treatment in hospital settings adapted to epidemiological circumstances. Having studied the instructions and recommendations of the competent authorities, as well as reviewing available literature, this paper presents the most important measures for the smooth performance of ECT in conditions associated with the COVID-19 disease.
\end{abstract}

Key words: COVID-19; pandemics; electroconvulsive therapy

Copyright @ 2021 KBCSM, Zagreb

e-mail: apr.kbcsm@gmail.com•www.http://apr.kbcsm.hr

\section{The reorganization of the healthcare system during the COVID-19 pandemic}

In March 2020, three months after the first cases surfaced in the Chinese city of Wuhan, WHO declared a global pandemic of the novel coronavirus, which by than had already spread through a great number of countries all over the world [1]. On the same day, March 11th, the Croatian Minister of Health declared an COVID-19 epidemic. On March 14th of 2020, in accordance with the Croatian Health

Correspodence to:

Ante Silić, MD, PhD

University Hospital Centre Sestre

Milosrdnice,Department of Psychiatry,

Vinogradska 29, Zagreb, Croatia

E-mail:ante.silic@gmail.com
Care Act, the Minister also established the Decision on measures for mobilization and organization of work of all health care institutions and health workers in the public health service network according to the needs of epidemic prevention and suppression. Anti-epidemic measures have been introduced. The Croatian Institute for Public Health and the Croatian National Civil Protection Authority, as well as other governmental agencies, have issued a number of instructions and recommendations in order to protect the health of health care workers and patients. In those days, the strongest earthquake that Zagreb experienced in the last 140 years occurred, which further aggravated the already challenging situation. During March and April, in accordance with 
the instructions of the Ministry of Health, the everyday hospital activity was to be restricted with a reduction of the number of deferrable patients to a minimum. Only nondeferrable and urgent examinations and diagnostic procedures were carried out. Triage was introduced at the entrances to health institutions, which included body temperature measurement as well as a questionnaire on potential contacts and a signed statement in which symptoms pointing to COVID-19 were negated. Also, a mandatory negative PCR test for SARS-CoV-2 was introduced for certain situations, as well as other preventive measures, such as ordering patients in advance, the ban on visits to the hospitals and an increase of telecommunication usage. With the improvement of the epidemiological situation in May, new measures for the reactivation of the hospital care system were introduced, which led to the gradual return of health care services to their previous scope.

In such circumstances, psychiatry found itself faced with various challenges, one of them being the preservation of the continuity of electroconvulsive therapy (ECT) in patients with severe or refractory psychiatric disorders. ECT is still considered as one of the most effective and safest therapeutic interventions in psychiatry, especially in life threatening conditions that require a rapid therapeutic response (significant suicidality, progressive clinical deterioration, catatonia) [2]. In addition, it is extremely important for patients suffering from severe depression, schizophrenia or mania, that have an unsatisfactory therapeutic response to medication and/or psychotherapy [3-5]. From January 2020, ECT was resumed at the Clinical Hospital Centre Sestre Milosrdnice, and continued during the epidemic, with the exception of spring, when the program was temporarily suspended for two months (lockdown). In December 2020, after a new earthquake with an epicentre around Petrinja hit, the Clinical Hospital Centre of Zagreb was reorganized and our Clinic remained the only one in the country with the possibility of applying this therapeutic procedure. Thus, the importance of continuous and undisturbed performance of ECT in epidemic conditions has become even greater.

\section{Recommendations for COVID-19 disease prevention}

\section{Testing}

As with other patients undergoing surgery under general anesthesia, testing for SARSCoV-2 should be included in preparation for the procedure. The test result should not be older than 48 hours. In hospital patients it is recommended for a PCR test to be conducted once a week $[6,7]$.

\section{Personal protective equipment}

The use of personal protective equipment (PPE) is mandatory for all staff working with ECT. It includes the N95/FFP2 mask or an equivalent, goggles, a face shield, gloves and an isolation gown. Also, the number of staff in contact with the patient should be reduced to a minimum $[2,6,8]$.

\section{Ventilation}

The manual ventilation, done through a oro-nasal mask, is counted among the procedures which create aerosol and probably presents the biggest risk for infection among hospital staff [9]. SARS-CoV-2 has a high affinity for salivary gland cells, and those infected can secrete a significant quantity of the virus through their saliva; during the ventilation process the virus can then pass from the oral cavity into the aerosol [10]. That is why the use of PPE equipment is mandatory, and it includes the N95/FFP2 mask, as well as proper ventilation of the work-space. Adequate preoxygenation also plays an important part be- 
cause it increases patient apnea tolerance time and reduces the need for manual ventilation. The use of virus filters prevents the contamination of the self-inflating bag with the oxygen reservoir; in case the filters are changed after each patient, cleaning and maintenance can be done according to the manufacturer instructions [11].

\section{Cleaning and disinfection}

Depending on the type of material and environmental conditions, SARS-CoV-2 virus can survive on surfaces for up to several days, whereas in the air it can survive for over three hours [12]. Therefore, it is important to regularly clean the premises and disinfect all surfaces. Cleaning of the premises should be done once or twice a day by personnel designated for that purpose. When performing cleaning work, it is also necessary to wear adequate protective equipment and limit the time spent in the room. After each patient, a disinfection of the ECT device, anaesthetic machine, monitor and all other potentially contaminated surfaces is required; this should be done with a registered disinfectant that has an effect on viruses [13].

\section{References}

1. World Health Organization. WHO Director-General's opening remarks at the media briefing on COVID-19. [Internet]. 2020. [cited $11^{\text {th }}$ March 2020]. Available from: https://www.who.int/director-general/speeches/detail/who-director-general-s-opening-remarks-at-themedia-briefing-on-covid-19---11-march-2020.

2. Bellini H, Cretaz E, Rigonatti LF, De Conto CDR, Melzer-Ribeiro DL, Busatto-Filho G, et al. Electroconvulsive therapy practice during the COVID-19 pandemic. Clinics (Sao Paulo). 2020;75:e2056.

3. Baghai TC, Möller HJ. Electroconvulsive therapy and its different indications. Dialogues Clin Neurosci. 2008;10:105-17.
ECT allows for an adequate and timely treatment of severe psychiatric disorders such as severe depression with suicidality, catatonia or refractory schizophrenia. Such patients are a priority and demand immediate treatment in hospital settings adapted to epidemiological circumstances. Having studied the recommendations of the Ministry of Health, the National Civil Protection Authority and the Croatian Institute for Public Health, as well as reviewing available literature, several measures of disease prevention can be singled out, such as patient testing, PPE equipment use, slight modifications of the anesthesia procedures as well as an adequate hygiene of the space used by patients.

\section{Acknowledgements}

None.

\section{Conflicts of interest}

None to declare.

\section{Funding Sources}

None.
4. Kellner CH, Obbels J, Sienaert P. When to consider electroconvulsive therapy (ECT). Acta Psychiatr Scand. 2020;141:304-15.

5. McIntyre RS, Filteau M-J, Martin L, Patry S, Carvalho A, Cha DS, et al. Treatment-resistant depression: definitions, review of the evidence, and algorithmic approach. J Affect Disord. 2014;156:1-7.

6. Sienaert P, Lambrichts S, Popleu L, Van Gerven E, Buggenhout S, Bouckaert F. Electroconvulsive Therapy During COVID-19-Times: Our Patients Cannot Wait. Am J Geriatr Psychiatry. 2020;28:772-5.

7. Gil-Badenes J, Valero R, Valentí M, Macau E, Bertran MJ, Claver $\mathrm{G}$, et al. Electroconvulsive therapy protocol adaptation during the COVID-19 pandemic. J Affect Disord. 2020;276:241-8. 
8. Bryson EO, Aloysi AS. A Strategy for Management of Electroconvulsive Therapy Patients During the COVID-19 Pandemic. J ECT. 2020;36:149-51.

9. Surve RM, Sinha P, Baliga SP, Radhakrishnan M Karan $\mathrm{N}$, Anju Jl, et al. Electroconvulsive therapy 'services during COVID-19 pandemic. Asian J Psychiatr. 2021;59:102653.

10. Walls AC, Park YJ, Tortorici MA, Wall A, McGuire AT, Veesler D. Structure, function, and antigenicity of the SARS-CoV-2 spike glycoprotein. Cell. 2020;181:281292.e6.

11. Kim HJ, Ko JS, Seo H, Kim TY. Guidelines for the control and prevention of coronavirus disease (COVID-19) transmission in surgical and anesthetic settings. Korean J Anesthesiol. 2020;73:271-4.

12. van Doremalen N, Bushmaker T, Morris DH, Holbrook MG, Gamble A, Williamson BN, et al. Aerosol and surface stability of HCoV-19 (SARS-CoV-2) compared to SARS-CoV-1. N Engl J Med. 2020;382:1564-7.

13. World Health Organization. Cleaning and disinfection of environmental surfaces in the context of COVID-19 [Internet]. 2020. [cited 11 ${ }^{\text {th }}$ March 2020]. Available from: https://apps.who.int/iris/bitstream/ handle/10665/332096/WHO-2019-nCoV-Disinfection-2020.1-eng.pdf? sequence $=1$ \&is Allowed $=\mathrm{y}$

\section{Elektrokonvulzivna terapija tijekom pandemije COVID-19}

Sažetak - u ožujku 2020., tri mjeseca nakon prvih zabilježenih slučajeva u kineskom gradu Wuhan, WHO je proglasio globalnu pandemiju novootkrivenog koronavirusa koji je do tada već zahvatio veliki broj država širom svijeta. U svrhu zaštite zdravlja zdravstvenih radnika i pacijenata, poduzete su aktivnosti i mjere za sprječavanje širenja bolesti COVID-19 u zdravstvenom sustavu, pri čemu se u psihijatriji kao jedan od izazova nametnulo osiguravanje kontinuiteta elektrokonvulzivne terapije (EKT-a) kod osoba s teškim i rezistentnim psihijatrijskim poremećajima. Takvi pacijenti su prioritetni i zahtijevaju neodgodivo liječenje u bolničkim uvjetima prilagođenim epidemiološkim okolnostima. Proučivši upute i preporuke nadležnih tijela te pregledom dostupne literature, u ovom radu se predstavljaju najvažnije mjere za neometano izvđenje EKT-a u uvjetima povezanima s bolesti COVID-19.

Ključne riječi: COVID-19; pandemija; elektrokonvulzivna terapija 